\title{
Upaya Pemberdayaan Petani Kelapa (Cocos Nucifera) di Desa Pesaban, Kecamatan Rendang, Kabupaten Karangasem
}

\author{
NI KOMANG TRI ASTRINI, I MADE SARJANA, I GEDE SETIAWAN ADI \\ PUTRA.
}

\author{
Program Studi Agribisnis, Fakultas Pertanian, Universitas Udayana \\ J1. PB. Sudirman Denpasar 80323. \\ E-mail : mangtri24@gmail.com \\ sarjanasosek@yahoo.com
}

\section{Abstract \\ Coconut Farmers Empowerment Effort (Cocos Nucifera) in the Village of Pesaban, Sub-District of Rendang, Regency of Karangasem.}

Pesaban Village, Rendang Sub-District of Karangasem Regency has great coconut potential, but farmers can't utilize the condition properly. The purpose of this research is to investigate: (1) coconut farming potential, (2) aspect and effort of empowering the coconut farmers. The research uses qualitative and quantitative analysis methods. The results showed that the potential of natural resources of coconut farming, human resources, and financial resources are good. Ownership of assets is good and belongs to the farmers themselves, relationships between individuals and groups are well established, coconut farmers have organizations to cooperate, and the partnership synergy of coconut farmers with the local and outside traders. Access to information is very less, the participation of the group has been well built, coconut farmers have a sense of responsibility in maintaining the good quality of the product, group forums have not fully be a problem-solving.

Keywords: potential, process, empowerment, coconut farmers

\section{Pendahuluan}

\subsection{Latar Belakang Masalah}

Kelapa merupakan komoditi strategis yang memiliki peran sosial, budaya, ekonomi dalam kehidupan masyarakat Indonesia. Manfaat tanaman kelapa tidak hanya pada daging buahnya yang bisa diolah menjadi santan, kopra, dan minyak kelapa tetapi seluruh bagian tanaman kelapa mempunyai manfaat yang besar. Besar manfaat tanaman kelapa sehingga ada yang menyebut sebagai "pohon kehidupan" (the tree of life) atau "pohon yang amat menyenangkan" (a haven tree) (Asnawi dan Darwis, 1985). Pohon kelapa disebut sebagai pohon kehidupan, hal ini berarti kelapa diyakini mampu menghidupkan perekonomian masyarakat (petani). Kondisi ini menginspisari petani di 
Kabupaten Karangasem yang membudidayakan padi sawah beralih dan kembali pada komoditas perkebunan. Kondisi ini disebabkan dua faktor, yaitu : (1) menurunnya debit air irigasi yang disebabkan oleh kerusakan lingkungan dan (2) petani harus memiliki pendapatan untuk memenuhi kebutuhan hidup keluarga. Bagian-bagian dari pohon kelapa yang dimanfaatkan adalah janur, buah kelapa tua, buah kelapa muda, dan yang lainnya. Janur menjadi kebutuhan pokok masyarakat di Bali untuk keperluan berbagai upacara keagamaan yang setiap tahunnya menghabiskan tidak kurang 360 ribu ton janur. Peningkatan permintaan janur untuk keperluan sarana upakara ini akan menjadikan budidaya kelapa menjadi salah satu komoditi yang memiliki nilai tinggi. Secara tradisional penggunaan produk kelapa untuk konsumsi segar, dibuat kopra atau minyak kelapa (Departemen Pertanian, 2007).

Bali sebagai pulau kecil tercatat memiliki areal tanaman kelapa sekitar 70.609 hektar, namun dari tanaman tersebut ada 1.445 hektar sudah berusia tua dan rusak, sehingga tidak produktif lagi. Produksi buah kelapa di bali rata-rata mencapai 66.838,62 ton per tahun, untuk meningkatkan populasi dan produksi tanaman kelapa, Dinas Perkebunan Bali berupaya melakukan peremajaan dan mengintensifkan pemeliharaanya (Metrotvnews, 2014).

Kelapa menjadi salah satu komoditas unggulan yang dibudidayakan petani di desa Pesaban. Pertimbangan ini didasari mengingat kelapa merupakan tanaman yang serbaguna dan memiliki nilai ekonomis tinggi sebagai sumber pendapatan petani. Pengolahan produksi oleh petani mempunya kualitas yang rendah. Banyak orang mengaitkan bahwa rendahnya mutu tersebut dikarenakan cara-cara pengolahan hasil pertanian masih bersifat tradisional. Mengingat geografis Kabupaten Karangasem yang memiliki potensi dalam hal perkebunan kelapa rakyat, namun kenyataan di lapangan, Kabupaten Karangasem yang memiliki luas perkebunan 28.326,57 hektar belum mampu dimanfaatkan dengan baik oleh petani (Awang, 1991).

Kondisi ini juga terjadi di Desa Pesaban yang terletak di Kecamatan Rendang, Kabupaten Karangasem yang sebagian besar luas wilayahnya merupakan perkebunan, persawahan sedangkan pemukiman hanya sebagian kecil saja, dengan demikian di Desa Pesaban memiliki potensi di bidang pertanian. Potensi ini terdapat di daerah Dusun Pesaban kangin dan Pesaban kaler yang merupakan daerah perkebunan, dan sebagian besar ditanami dengan komoditi kelapa. Desa Pesaban memiliki potensi sumber daya alam yang kaya, letak geografinya yang baik karena tumbuh di daerah pegunungan dengan kandungan unsur hara yang lebih banyak dan strategis untuk aktivitas bercocok tanam.

Lahan kelapa yang dikelola masing-masing petani cukup luas yaitu antara kisaran 0,75 s.d 1 hektar, berdasarkan observasi pendahuluan produktifitas perkebunan kelapa belum optimal, karena tergolong lahan keritis dengan pemeliharaan seadanya atau tidak sama sekali, dan masih dikelola secara tradisional sehingga masih dalam skala kecil, hal ini juga disebabkan petani kurang inovasi dalam membudidayakan kelapa. Pendapatan Kelompok Tani Busah dari hasil budidaya tanaman kelapa masih tergolong rendah. 
Petani ternyata belum memahami bagaimana memanfaatkan kekayaan alam yaitu kelapa yang begitu banyak. Petani bukan tidak mungkin bisa memperoleh keuntungan yang besar, apabila usaha tani kelapa dikelola secara baik, mengingat sumber daya yang melimpah dan semua bagian dari tanaman kelapa yang dapat dimanfaatkan menjadi produk yang bernilai ekonomis tinggi. Potensi ini seharusnya bisa dimanfaatkan dengan baik oleh petani di Desa Pesaban.

Petani membutuhkan dukungan dari lembaga untuk mengayomi dan membimbing agar kegiatan usahataninya lebih terorganisir. Kurangnya pemberdayaan pada usahatani kelapa di Kelompok Tani Busah di Desa Pesaban khususnya dalam pengolahan kelapa menjadi berbagai olahan ataupun kerajinan tangan, tetapi banyak dari petani memilih menjual kelapanya langsung kepada pengepul. Cara ini dianggap lebih praktis dikarenakan pengepul langsung datang ke kebun dan memanen sendiri buah kelapa tanpa harus merepotkan petani untuk memanen terlebih dahulu tetapi memang harga yang diberikan cenderung lebih murah. Hal ini tidak akan terjadi jika petani mampu memanfaatkan peluang yang ada untuk dapat menjadikan usahatani kelapa menjadi sumber pendapatan utama petani. Perlu diubah sistem usahatani tradisional menjadi suatu sistem dan usaha agribisnis berbasis olahan kelapa yang berdaya saing dan memiliki kualitas yang baik.

\subsection{Rumusan Masalah}

Berdasarkan uraian latar belakang diatas maka dapat dirumuskan masalah penelitian sebagai berikut.

1. Bagaimana potensi usahatani kelapa yang dimiliki petani di Desa Pesaban?

2. Bagaimana upaya pemberdayaan petani kelapa Desa Pesaban?

\subsection{Tujuan}

Berdasarkan perumusan masalah diatas maka tujuan yang ingin dicapai dalam penelitin ini sebagai berikut.

1. Mengetahui potensi usaha tani kelapa yang dimiliki oleh petani di Desa Pesaban, Kecamatan Rendang, Kabuaten Karangasem

2. Menganalisis upaya pemberdayaan petani kelapa di Desa Pesaban, Kecamatan Rendang, Kabupaten Karangasem.

\section{Metodologi Penelitian}

\subsection{Lokasi dan Waktu Penelitian}

Penelitian ini berlokasi di Desa Pesaban, Kecamatan Rendang, Kabupaten Karangasem. Pemilihan lokasi penelitian dilakukan secara sengaja (purvosive) yang didasarkan atas beberapa pertimbangan. Pengumpulan data untuk memperoleh bahan analisis dilaksanakan dari bulan Maret 2017 s.d Agustus 2017, terhitung dari proses pengumpulan data sampai dengan proses penulisan hasil penelitian. 


\subsection{Jenis dan Sumber Data}

Jenis data yang digunakan dalam penelitian ini adalah data kualitatif dan data kuantitatif. Data kualitatif adalah data yang berupa keadaan, proses, kejadian yang dijelaskan dalam bentuk perkataan, tidak berupa angka yang tidak dapat dihitung, seperti sumber daya alam, hubungan, reformasi kelembagaan, jejaring/kemitraan kerja, aksibilitas informasi, partisipasi, akuntabilitas dan kapasitas organisasi lokal. Data kuantitatif adalah data yang merupakan angka-angka yang dapat diukur dalam satuan tertentu dan dapat dihitung secara statistik dan matematik, ketersediaan lahan, sumber daya manusia, sumber daya finansial dan kepemilikan aset. Sumber data terdiri dari data primer dan sekunder. Data primer merupakan data yang diperoleh secara langsung dari sumbernya yaitu data melalui wawancara dan pengisian dapat pertanyaan (kuesioner) kepada para responden. Data sekunder merupakan data yang berupa dokumen-dokumen yang diperoleh secara tidak langsung yang diperoleh dari kantor desa dan instansi lainnya seperti data tentang gambaran umum lokasi penelitian.

\subsection{Teknik Pengumpulan Data}

Metode pengumpulan data yang digunakan dalam penelitian ini yaitu wawancara dan observasi. Wawancara (interview) yaitu teknik pengumpulan data dengan berhadapan secara langsung dan mewawancarai responden yang telah ditetapkan. Observasi merupakan pengamatan langsung para pembuat keputusan berikut lingkungan fisiknya dan atau pengamatan langsung suatu kegiatan yang sedang berjalan di lokasi penelitian yaitu di Desa Pesaban, Kecamatan Rendang, Kabupaten Karangasem untuk mengetahui kondisi dan fakta-fakta yang ada.

\subsection{Populasi Dan Responden}

Populasi penelitian ini adalah petani kelapa yang tergabung dalam Kelompok Tani Busah yang ada di Desa Pesaban, Kecamatan Rendang, Kabupaten Karangasem yang berjumlah 15 orang. Teknik sensus ini membuat seluruh populasi menjadi responden dalam penelitian ini, sehingga jumlah responden penelitian ini sebanyak 15 orang.

\subsection{Variabel Penelitian dan Pengukuran}

Variabel yang diteliti adalah upaya pemberdayaan petani kelapa, yang menampilkan variabel, indikator, parameter, dan skala pengukuran. Skala pengukuran yang digunakan adalah skala ordinal 1-5. Nilai 1 merupakan skor minimal dan skor 5 merupakan skor maksimum.

\subsection{Batasan Operasional}

Batasan-batasan penelitian ini mengenai sumber daya alam, sumber daya finansial, kemampuan sumber daya manusia, kepemilikan aset, hubungan antara individu dan kelompok, pengembangan kemitraan, aksebilitas informasi, partisipasi, akuntabilitas dan kapasitas organisasi lokal. 


\subsection{Analisis Data}

Analisis data yang digunakan adalah analisis data deskripsi kualitatif. Metode tersebut penulis berusaha menggambarkan dan menjelaskan mengenai pemberdayaan petani kelapa di Desa Pesaban, Kecamatan Rendang, Kabupaten Karangasem. Menurut Sugiyono, (2010) analisis data merupakan proses mencari dan menyusun secara sistematis data yang diperoleh dari hasil wawancara, catatan lapangan, dan proses dokumentasi.

\section{Hasil dan Pembahasan}

\subsection{Potensi}

Potensi dalam penelitian ini yang ingin diketahui a) Sumber Daya Alam b) Sumber Daya Manusia c) Sumber Daya Finansial untuk mengetahui pencapaian dari masing-masing potensi tersebut dapat dilihat pada tabel 1.

Tabel 1.

Kategori Potensi Petani Kelapa di Desa Pesaban, Kecamatan Rendang, Kabupaten Karangasem, Tahun 2017

\begin{tabular}{llcc}
\hline No & Variable sumber potensi & Rata-rata skor & Kategori \\
\hline 1 & Sumber Daya Alam & 3,74 & Tinggi \\
2 & Manusia & 3,44 & Tinggi \\
3 & Finansial & 4,11 & Tinggi \\
\hline & Potensi Petani Kelapa & 3,76 & Tinggi \\
\hline
\end{tabular}

\subsubsection{Sumber daya alam}

Pencapaian skor yang diperoleh rata-rata 3,74 dengan kategori tinggi. Terdapat lima indikator dalam variabel sumber daya alam ini diantaranya adalah, kesuburan tanah, potensi lahan, ketersediaan air, iklim, dan daerah tropis, masing-masing dari indikator ini tergolong dalam kategori baik yang mengindikasikan bahwa potensi dalam bidang sumber daya alam masih sangat besar dalam upaya pemberdayaan. Pernyataan ini sejalan dengan Kartasapoetra (1993), menyebutkan bahwa suhu udara berperan hampir pada semua proses pertumbuhan. Setiap jenis tanaman mempunyai batas suhu minimum, optimum dan maksimum yang berbeda-beda untuk setiap tingkat pertumbuhannya. Suhu optimum ialah suhu di mana tumbuhan dapat tumbuh dan berkembang dengan baik dan maksimal. Suhu paling rendah yang masih memungkinkan suatu tumbuhan untuk tumbuh disebut suhu minimum sedangkan suhu tertinggi yang masih memungkinkan tumbuhan untuk tumbuh disebut suhu maksimum. Suhu udara merupakan faktor dalam menentukan tempat dan waktu penanaman yang cocok, bahkan suhu udara dapat juga sebagai faktor penentu dari pusat-pusat produksi tanaman, misalnya kentang di daerah bersuhu rendah sebaliknya padi di daerah bersuhu tinggi. 


\subsubsection{Sumber daya manusia}

Diperoleh pencapaian skor rata-rata 3,44 yang tergolong dalam kategori tinggi. Terdapat tujuh indikator dalam variabel sumber daya manusia ini dengan empat diantaranya tergolong dalam kategori baik yaitu pengetahuan, keterampilan, pekerjaan sendiri dan kekonsistenan petani dalam membudidayakan tanaman kelapa. tiga indikator lainnya yaitu keterlibatan anggota keluarga, variasi olahan dan penerimaan inovasi, masuk dalam kategori sedang hal ini disebabkan karena tidak semua anggota keluarga ikut dalam pengolahan kelapa sehingga menyebabkan variasi olahan yang dihasilkan petani cenderung sedikit. sejalan dengan Planck, (1990) yang menyatakan cara berpikir petani diturunkan dari generasi tua ke generasi muda dalam perjalanan sosialisasi primer. Tercipta model perilaku yang berorientasi pada sistem nilai dan diikuti dengan patuh untuk jangka waktu lama, meskipun situasi yang menjadi dasarnya sudah lama berubah. Kesulitan mengubah cara berpikir juga terlihat jika mengambil alih suatu pembaharuan, misalnya jenis bibit tertentu yang lebih efisien, tanpa diikuti usaha yang diperlukan untuk menjamin keberhasilannya.

\subsubsection{Sumber daya finansial}

Pencapaian skor sumber daya finansial rata-rata 4,11 yang tergolong dalam kategori tinggi. Variabel sumber daya finansial ini memiliki tiga indikator diantaranya adalah penggunaan modal sendiri, bahan baku, dan tenaga kerja. Petani menggunakan modal sendiri dalam usaha tani kelapanya. Bahan baku yang digunakan didapatkan dengan mudah dan untuk tenaga kerja petani tidak mempekerjakan tenaga kerja dalam usaha taninya, maka dapat disimpulkan sumber daya finansi pada Kelompok Tani Busah ini tergolong baik. Sejalan dengan pendapat Tohir (1983) yang menyatakan tenaga kerja dalam usahatani memiliki karekteristik yang sangat berbeda dengan tenaga kerja di bidang usaha lain yang selain pertanian. Karakterisik tenaga kerja pertanian adalah sebagai berikut: (1) Keperluan akan tenaga kerja dalam usahatani tidak kontinyu dan tidak merata. (2) Penyerapan tenaga kerja dalam usaha tani sangat terbatas. (3) Tidak mudah distandarkan, dirasioalkan, dan dispesialisasikan. (4) Beraneka ragam coraknya dan kadang kala tidak dapat dipisahkan satu sama lain. Karakteristik diatas akan memerlukan sistem-sistem manejerial tertentu yang harus dipahami sebagai usaha peningkatan usahatani itu sendiri, khususnya di Indonesia sistem manejerial bisanya masih sangat sederhana.

\subsection{Aspek Pemberdayaan}

Ditinjau dari lingkup dan obyek mencakup beberapa aspek yakni kepemilikan aset, hubungan antar individu dan kelompok, reformasi kelembagaan, dan pengembangan kemitraan. Untuk mengetahui pencapaian dari masing-masing potensi tersebut dapat dilihat pada tabel 2 . 
Tabel 2.

Aspek Pemberdayaan Petani Kelapa pada Kelompok Tani Busah di Desa Pesaban, Kecamatan Rendang, Kabupaten Kerangasem, Tahun 2017

\begin{tabular}{llcc}
\hline No & Uraian & Rata-rata skor & Kategori \\
\hline 1 & Kepemilikan Aset & 4.00 & Tinggi \\
2 & Hubungan antar Individu dan Kelompok & 4,11 & Tinggi \\
3 & Reformasi Kelembagaan & 4,00 & Tinggi \\
4 & Pengembangan Kemitraan & 4,13 & Tinggi \\
\hline & Aspek Pemberdayaan Petani Kelapa & 4,06 & Tinggi \\
\hline
\end{tabular}

\subsubsection{Kepemilikan aset}

Kepemilikan aset dalam penelitian ini memperoleh pencapaian skor rata-rata 4,00 yang tergolong dalam kategori tinggi. Variabel kepemilikan aset ini terdapat dua indikator yaitu diantaranya lahan produksi dan sarana produksi. Responden menyatakan lahan produksi dan sarana produksinya tergolong dalam katagori baik. Lahan produksi adalah milik petani sendiri dan alat-alat pendukung yang dibutuhkan untuk usahatani kelapa juga milik petani hal ini tentu menjadi keuntungan dalam usahatani kelapa pada Kelompok Tani Busah.

\subsubsection{Hubungan antar individu dan kelompok}

Hubungan individu dengan kelompok memperoleh pencapaian skor 4,11 yang tergolong dalam kategori tinggi. Terdapat tiga indikator pada variabel hubungan antara individu dan kelompok diantaranya kerjasama antar petani, permasalahan, dan komunikasi. Kerjasama antar petani tergolong baik begitu juga pada indikator permasalahan dan komunikasi yang tergolong baik. Hubungan yang baik ini disebabkan antar petani tidak memiliki permasalahan satu sama lain dengan komunikasi yang baik sehingga petani mampu mengatasi permasalahan yang dihadapi. Homans (1950) menyatakan bahwa kelompok adalah sejumlah individu berkomunikasi satu dengan yang lain dalam jangka waktu tertentu yang jumlahnya tidak terlalu banyak

\subsubsection{Reformasi kelembagaan}

Reformasi kelembagaan memperoleh pencapaian skor 4.00 dengan indikator organisasi. Petani kelapa memiliki organisasi sebagai wadah untuk bekerjasama yang tergolong baik, kerjasama yang baik antar petani ini menjadi keuntungan tersendiri bagi petani kelapa pada Kelompok Tani Busah sehingga dapat mencapai tujuan yang diinginkan. Djogo (2003) menyatakan lembaga adalah aturan di dalam suatu kelompok masyarakat atau organisasi yang memfasilitasi koordinasi antar anggotanya untuk membantu mereka dengan harapandimana setiap orang dapat bekerjasama atau berhubungan satu dengan yang lainnya untuk mencapai tujuan bersama yang diinginkan. 


\subsubsection{Pengembangan kemitraan}

Pengembangan kemitraan memperoleh pencapaian skor 4,13 dengan kategori tinggi, dengan dua indikator yaitu berkerjasama dengan pedagang di luar Karangasem dan bekerjasama dengan pedagang diluar Bali. Kedua indikator tersebut tergolong dalam kategori baik petani kelapa memiliki akses bekerjasama dengan pedagang luar Karangasem seperti di Kabupaten Klungkung dan tidak jarang pedagang dari luar Bali datang untuk membeli kelapa yang dihasilkan petani, hal ini membuktikan pengembangan kemitraan untuk usahatani kelapa ini peluangnya masih terbuka lebar. Notoatmodjo (2003), menyatakan kemitraan adalah suatu kerja sama formal antara individu, kelompok, atau organisasi untuk mencapai suatu tugas atau tujuan tertentu.

\subsection{Unsur Pemberdayaan}

Unsur pemberdayaan masyarakat perlu memperhatikan empat unsur pokok yaitu aksebilitas informasi, partisipasi, akuntabilitas dan kapasitas organisasi lokal. pencapaian dari masing-masing potensi tersebut dapat dilihat pada tabel 3.

\section{Tabel 3.}

Unsur Pemberdayaan Petani Kelapa pada Kelompok Tani Busah Di Desa Pesaban, Kecamatan Rendang, Kabupaten Karangasem, Tahun 2017

\begin{tabular}{llcc}
\hline No & Uraian & Rata-rata skor & Kategori \\
\hline 1 & Aksebilitas Informasi & 2,58 & Rendah \\
2 & Partisipasi & 4,11 & Tinggi \\
3 & Akuntabilitas & 4,00 & Tinggi \\
4 & Kapasitas Organisasi Lokal & 3,29 & Sedang \\
\hline & Unsur Pemberdayaan & 3,49 & Tinggi \\
\hline
\end{tabular}

\subsubsection{Aksibilitas informasi}

Aksebilitas informasi diperoleh pencapaian skor rata-rata 2,58 dengan kategori rendah. variabel aksibilitas informasi terdapat empat indikator yaitu diantaranya, upaya pemerintah desa, upaya PPL, upaya ketua kelompok, dan akses informasi. Rendahnya informasi seharusnya dapat di atasi oleh pemerintah desa dan PPL dengan pemberian informasi yang dibutuhkan petani terkait dengan usahatani kelapa, sehinga petani kelapa di Kelompok Tani Busah memiliki pengetahuan yang lebih luas tentang usahatani kelapanya. Syahyuti et al. (2003) menyebutkan tujuan yang ingin dicapai penyuluhan pertanian adalah mengembangkan kemampuan petani secara bertahap agar memiliki tingkat pengetahuan yang semakin meningkat, perbendaharaan informasi yang memadai dan kemampuan mengaplikasikan teknologi yang dibutuhkan sehingga akhirnya mampu memecahkan masalah serta mengambil keputusan yang terbaik untuk usahataninya. Jadi, penyuluhan pertanian bukan sekedar menyampaikan informasi kepada petani lalu berhenti, tetapi berlanjut sampai pada dampaknya yang ada efek perbaikan langsung yang menguntungkan. 


\subsubsection{Partisipasi}

Partisipasi diperoleh pencapaian skor rata-rata 4,11 pada variabel partisipasi terdapat empat indikator yang diantaranya adalah kehadiran dalam pertemuan, pemberian saran dan masukan, ikut menjaga lingkungan dan melakukan rembug, keempat indikator partisipasi tergolong dalam kategori baik, pertemuan yang dilakukan petani kelapa untuk diskusi memberi masuka dan saran kepada sesama petani kelapa pada proses usaha taninya, dalam hal ini kerjasama dan toleransi sangat baik terjalin antar anggota, anggota Kelompok Tani Busah di Desa Pesaban biasanya melakukan diskusi ringan antar anggota pada saat melakukan ngayah di pura desa yang dilakukan dua minggu sekali. Kelompok Tani Busah juga berpartisipasi dalam menjaga kelestarian alam dan sekitarnya tidak merusak lingkungan dan tidak menggunakan bahan-bahan kimia yang dapat membuat alam rusak, hal ini sudah menjadi kebiasaan yang dilakukan petani kelapa sejak dahulu kebiasaan menjaga lingkungan ini diwariskan dari keluarga terdahulu, mengingat di Bali terdapat istilah Tri Hita Karana yaitu keharmonisan hubungan manusia dengan tuhan, manusia dengan lingkungan, dan manusia dengan sesama.

\subsubsection{Akuntabilitas}

Hasil pengamatan diperoleh Kelompok Tani Busah di Desa Pesaban menyatakan akuntabilitas petani kelapa di Desa Pesaban, Kecamatan Rendang, Kabupaten Karangasem terhadap kualitas dan kuantitas olahan kelapa yang dihasilkan tergolong baik. Konsumen yang membeli olahan kelapa kepada para pengerajin kelapa saat merasa puas mereka kembali datang dan memesan pada petani kelapa di Kelompok Tani Busah. Umar, (2005) menyatakan kepuasan konsumen adalah tingkat perasaan konsumen setelah membandingkan antara apa yang dia terima dan harapkan, seorang pelanggan jika merasa puas dengan nilai yang diberikan oleh produk atau jasa, sangat besar kemungkinannya menjadi pelanggan dalam waktu yang lama.

\subsubsection{Kapasitas organisasi lokal}

Penelitian ini menunjukan bahwa kapasitas organisasi lokal pada petani kelapa di Kelompok Tani Busah ini tergolong sedang. Petani kelapa pada Kelompok Tani Busah menyatakan bahwa ketika terjadi permasalahan petani akan melakukan rembug untuk memecahkan masalah yang ada, meskipun terkadang tidak semua masalah dapat diselesaikan, sehingga dalam pemecahan masalah masuk dalam kategori sedang. Indikator rutin mengadakan pertemuan juga tergolong dalam kategori sedang. Ketua kelompok memiliki kesibukan lain selain sebagai petani kelapa yaitu sebagai pedagang sehingga terkadang menghambat kehadirannya pada saat rapat rutin diadakan, jika hal ini terus terjadi akan membuat contoh buruk bagi anggota lain. Penelitian ini Sejalan dengan pendapat Djiwandi (1994) Mengembangkan kelompok tani berarti membangun kemauan, dan kepercayaan pada diri sendiri agar dapat terlibat secara aktif dalam pembangunan. Mereka dapat bergerak secara metodis, berdayaguna, dan terorganisir. 


\section{Simpulan dan Saran \\ 4.1 Simpulan}

Simpulan potensi sumber daya alam di Desa Pesaban kesuburan, lahan, air dan iklim di desa pesaban sangat cocok untuk budidaya tanaman kelapa. Sumber daya manusia tergolong baik dan sumber daya finansial juga tergolong baik. Aspek-aspek dan unsur-unsur pemberdayaan mengenai kepemilikan aset tergolong baik dengan skor rata-rata 4,00. Hubungan anatar individu dan kelompok tergolong baik dengan skor rata-rata 4,11. Reformasi kelembagaan tergolong baik dengan skor rata-rata 4,00. Pengembangan kemitraan tergolong baik dengan skor rata-rata 4,13. Aksebilitas informasi tergolong rendah. Partisipasi fisik dalam usaha pengembangan usahatani kelapa tergolong baik. Kemampuan bertanggung jawab petani tergolong sedang.

\subsection{Saran}

Berdasarkan temuan dalam penelitian ini maka dapat disarankan hal-hal berikut. (1) Upaya pemeberdayaan petani kelapa di Desa Pesaban perlu lebih dimaksimalkan oleh semua pihak agar petani kelapa termotivasi untuk meningkatkan usahataninya; (2) Pemerentah perlu lebih memperhatikan petani kelapa dan memberikan dukungan dan bantuan berupa pelatihan yang dapat membuat petani kelapa lebih bersemangat untuk meningkatkan usahataninya; (3) Perlu adanya lembaga yang mengayomi dan mengorganisasi petani sehingga keberadaannya tidak lagi terpinggirkan sehingga mampu mendapatkan pemberdayaan yang lebih baik sehingga dapat menambah pendapatan petani kelapa; dan (4) Ketua kelompok diharapkan lebih bisa memberikan contoh kepada anggotanya untuk lebih rajin/rutin menghadiri pertemuan-pertemuan yang diadakan oleh kelompok.

\section{Ucapan Terimakasih}

Terimakasih kepada kepala Desa Pesaban, Kecamatan Rendang beserta jajaran atas izin yang telah diberikan kepada penulis, selanjutnya tidak lupa ucapan terimakasih kepada ketua kelpmpok tani busah Mangku Sintia beserta anggota kelompok yang telah meluangkan waktu untuk penulis mengadakan penelitian, hingga termuat di e-jurnal.

\section{Daftar Pustaka}

Asnawi, S. dan S.N. Darwis. 1985. Prospek Ekonomi Tanaman Kelapa dan Masalahnya di Indonesia. Terbitan Khusus No. 2/VI/1985. Balai Penelitian Kelapa, Manado. Diakses pada Tanggal 17 Desember 2016.

Awang, S.A. 1991. Kelapa Kajian Sosial Ekonommi. Aditya Media. Yogyakarta.

Deptan. 2007. Prospek dan Arah Pengembangan Agribisnis Kelapa Edisi Kedua. Deptan: Jakarta. Diakses pada Tanggal 12 November 2016.

Djogo Dkk. 2003. Analisi Kelembagaan, Skripsi, Fakultas Kehutanan UGM. Diakses pada Tanggal 22 November 2016. 
Djiwandi. 1994. Pengaruh Dinamika Kelompok Tani terhadap Kecepatan Adopsi Teknologi Usahatani di Kabupaten Sukoharjo.Prosiding Laporan Penelitian. Diakses pada Tanggal 12 November 2016.

Homans, G. C. 1950, The Human Group. Harcourt, Brace and Company, New York.

Husein Umar. 2005. Metode Penelitian. Salemba Empat. Jakarta.

Kartasapoetra Ance Gunarsih. 1993. Hama Tanaman Pangan dan Perkebunan. Bumi Aksara, Jakarta.

Metrotvnews. 2014 Bali Siapkan Rp 2 Miliar untuk Remajakan Kelapa 2014 http://news. Metrotvnews.com/daerah/Rkj5aO6b-bali-siapkan-rp2-miliar-untukremajakan-kelapa 12. Diakses pada Tanggal 16 November 2016.

Notoatmodjo S. 2003. Pendidikan dan Perilaku Kesehatan, Rineka Cipta, Jakarta. Diakses pada Tanggal 16 November 2016.

Syahyuti. 2003. Bedah Konsep Kelembagaan: Strategi Pengembangan dan Penerapannya dalam Penelitian Pertanian. Pusat Penelitian dan Pengembangan Sosial Ekonomi Pertanian, Bogor. Diakses pada Tanggal 22 November 2016.

Tohir. A Kaslan. 1983. Seuntai Pengetahuan Tentang Usahatani Indonesia. Bina Aksara. Jakarta

Planck U. 1993. Sosiologi Pertanian. (Terjemahan oleh: Titi Soentaro dan Soeyanto). Yayasan Obor Indonesia. Jakarta. Diakses pada Tanggal 12 Januari 2017. 